\title{
Peranan Alat Perlengkapan Organisasi dan Pengawasan Dalam Menunjang Kinerja Karyawan Pada Koperasi Green Society Palembang
}

\author{
Oktariansyah \\ Akuntansi, Fakultas Ekonomi Universitas PGRI Palembang \\ email: rianbro82@univpgri-palembang.ac.id
}

\begin{abstract}
ABSTRAK
Rumusan masalah pada penelitian ini bagaimanakah peranan alat perlengkapan organisasi dan pengawasan dalam menunjang kinerja karyawan pada Koperasi Green Society Palembang. Hasil penelitian yang dilakukan penulis menunjukkan bahwa Koperasi tidak berbeda dengan organisasi lainnya yang dapat berjalan secara efektif apa bila perencanaan yang telah dibuat dapat dilaksanakan sebagaimana mestinya dalam mencapai tujuan. Hal ini harus di dukung oleh para pelaksanaan dan administrasi yang baik, di samping volume usaha dan perkembangan unit-unitnya di dalam Koperasi Green Society Palembang itu masih terdapat beberapa kelemahan diantaranya : Tertib Administrasi atau Tertib Dokumen belum dilaksanakan sebagaimana mestinya dan masih harus disempurnakan, dalam Organisasi Koperasi Green Society Palembang ternyata pengurus harian belum melaksanakan tugas-tugasnya dengan baik namun organisasi unit-unitnya sudah berjalan sesuai dengan ketentuan perkoperasian, dan fungsi pengawasan baik oleh petugas di lingkungan atau di bawah manager maupun dari pengurus belum dijalankan sebagaimana mestinya
\end{abstract}

Kata Kunci: Alat Perlengkapan Organisasi, Pengawasan, Kinerja Karyawan.

\section{A. Latar Belakang}

Salah satu sektor yang berperan dalam meningkatkan perekonomian Indonesia adalah koperasi, seperti kita ketahui sektor koperasi merupakan salah satu sektor yang perkembangannya mendapatkan perhatian besar dari pemerintah.

Menurut Fay dalam Hendrojogi (2012), koperasi adalah suatu perserikatan yang dibuat dengan tujuan berusaha bersama, terdiri dari mereka yang lemah dan diusahakan untuk tidak memikirkan diri sendiri sedemikian rupa, sehingga masingmasing sanggup menjalankan kewajibannya sebagai anggota dan mendapat imbalan yang sebanding dengan pemanfaatan mereka terhadap organisasi.

Berdasarkan Undang-Undang No. 17 Tahun 2012, "Koperasi adalah badan hukum yang didirikan oleh orang perseorangan atau badan hukum Koperasi, dengan pemisahan kekayaan para anggotanya sebagai modal untuk menjalankan usaha yang memenuhi aspirasi dan kebutuhan bersama di bidang ekonomi, sosial, dan budaya sesuai dengan nilai dan prinsip koperasi. Pengembangan dan pemberdayaan koperasi nasional dalam kebijakan pemerintah selayaknya mencerminkan nilai dan prinsip perkoperasian sebagai wadah usaha bersama untuk memenuhi aspirasi dan kebutuhan ekonomi anggotanya. (Hendrojogi, 2012).

Sebagaimana telah ditetapkan Pemerintah dalam Pasal 33 UUD 1945 ayat 1 amandemen keempat yang berbunyi: "Perekonomian disusun sebagai usaha bersama berdasar atas asas kekeluargaan" (Tim Penyusun, 2004). Hal ini menunjukkan adanya pengarahan terhadap segi-segi perekonomian dengan penekanan terhadap azas kerjasama kegotong royongan. Selaras dengan makna yang terkandung dalam Pasal 33 ayat 1 
UUD 1945 tersebut menunjukkan bahwa pemerintah telah memberikan peluang terhadap tumbuh suburnya perkoperasian di Indonesia.

Selanjutnya, dalam Garis-Garis Besar Haluan Negara (GBHN) ditetapkan bahwa pelaksanaan pembangunan nasional adalah dengan memanfaatkan segenap kemampuan modal dan potensi dalam negeri disertai dengan kebijaksanaan serta langkah-langkah guna membantu, membimbing pertumbuhan dan meningkatkan kemampuan yang lebih besar bagi golongan ekonomi lemah untuk berpartisipasi dalam proses pembangunan sehingga dapat berdiri sendiri, antara lain dengan peningkatan kegiatan koperasi, agar mampu memainkan peranan yang sesungguhnya dalam tata ekonomi Indonesia.

Berdasarkan kutipan di atas, dapat diketahui bahwa pemerintah senantiasa berusaha meningkatkan peranan koperasi dalam proses pembangunan nasional terutama dalam kegiatan ekonomi nasional. Dalam rangka pengembangan koperasi, GBHN menetapkan bahwa pembinaan koperasi ditujukan agar tumbuh menjadi lembaga ekonomi yang kuat dan menjadi wadah utama untuk pembinaan kemampuan golongan ekonomi lemah. Sehubungan dengan hal tersebut, maka perlu ditingkatkan kesadaran berkoperasi serta langkah-langkah pembinaan dan penyuluhan untuk mengembangkan koperasi. Selain itu, dilanjutkan pula dengan bantuan dan pemberian fasilitas seperti penyediaan kredit dengan syarat yang dipermudah guna pengadaan sarana produksi yang dibutuhkan, bantuan tenaga manajemen dan lain-lain.

Pada masa pembangunan ini, koperasi mempunyai peranan aktif dalam menunjang lajunya pertumbuhan usaha pembangunan. Untuk mewujudkan peranan koperasi tersebut maka setiap jenis usaha dalam kesatuan kerja membutuhkan adanya pengelolaan yang baik serta berfungsinya alat dan perlengkapan organisasi koperasi tersebut dan mendapatkan dukungan dari para anggotanya.

Menurut Undang-Undang Nomor 17 tahun 2012, yang termasuk alat kelengkapan organisasi terdiri dari : (1) Rapat anggota, (2) Pengurus, dan (3) Pengawas. Keberhasilan organisasi koperasi sangat bergantung pada berfungsi atau tidaknya alat perlengkapan organisasi tersebut.

Pengurus yang baik tanpa adanya dukungan dari anggota secara aktif, maka koperasi tersebut akan berjalan lamban (pasif). Demikian juga pengurus yang baik dan anggota yang aktif tanpa adanya dukungan pengawasan yang baik akan menimbulkan adanya kecenderungan terjadinya penyimpangan dan sulit untuk mengetahui sampai dimana keberhasilan pencapaian tujuan yang telah ditetapkan dalam rapat anggota.

Sebagaimana koperasi lainnya, Koperasi Green Society Palembang yang berdiri sejak tahun 2002 merupakan salah satu koperasi yang memiliki peranan penting dalam menggerakkan ekonomi rakyat di pedesaan, hal ini dapat dilihat dari luasnya jangkauan usaha koperasi ini yakni di Kabupaten Ogan Komering Ulu (OKU), Kabupaten Ogan Komering Ulu Timur (OKU Timur), Kabupaten Ogan Komering llir (OKI), dan Kabupaten Ogan llir (OI). Namun dalam pelaksanaan kegiatan-kegiatan organisasi masih terdapat beberapa masalah yang dihadapi terutama dalam bidang organisasi dan pengawasannya yang pada akhirnya dapat menganggu kinerja karyawan di koperasi tersebut. Permasalahan tersebut di antaranya 
adalah keputusan yang diambil oleh ketua koperasi terkadang berbeda keputusan yang diambil oleh para pengurus koperasi. Perbedaan ini pada akhirnya mengakibatkan kebingungan karyawan pada tingkat lapangan. Selain itu, permasalahan lainnya yakni pengawasan, karena terlalu luasnya ruang lingkup koperasi ini, maka pengawasan yang dilakukan terkadang menemui hambatan terutama dalam hal pengelolaan koperasi. Hambatan tersebut dengan sendirinya akan mempengaruhi kinerja karyawan yang pada akhirnya akan berakibat pada pencapaian tujuan organisasi itu sendiri. Selain itu, ketua koperasi seting tidak datang ke kantor koperasi karena kesibukannya di luar koperasi sehingga pengawasannya kurang efektif.

\section{B. Rumusan Masalah}

Bagaimanakah peranan alat perlengkapan organisasi dan pengawasan dalam menunjang kinerja karyawan pada Koperasi Green Society Palembang?

\section{Metode Penelitian}

Dalam penelitian ini, penulis menggunakan metode analisis deskriptif kualitatif, yakni mengumpulkan data, menyusun data, menyajikan data, menginterpretasikan data serta mengambil suatu kesimpulan atas data-data yang telah dikumpulkan tersebut.

\section{Populasi dan Sampel}

1) Populasi

Menurut Arikunto (2010), "Populasi adalah keseluruhan subjek penelitian". Adapun populasi dalam penelitian ini adalah semua karyawan pada Koperasi Green Society Palembang yang berjumlah 48 orang.

\section{2) Sampel}

Sampel adalah sebagian atau wakil populasi penelitian. Selanjutnya, apabila subjek yang diteliti kurang dari 100, lebih baik diambil semua sehingga penelitiannya merupakan penelitian populasi, sedangkan jika jumlah subjeknya lebih dari 100, maka diambil $10 \%-15 \%$ atau $20 \%-25 \%$ tergantung dari kemampuan peneliti yang dilihat dari segi waktu dan luasnya wilayah penelitian, Arikunto (2010).

Berdasarkan pendapat tersebut di atas, penulis mengambil keseluruhan populasi yang ada sebagai sampel dalam penelitian ini yakni sebanyak 48 orang.

\section{E. Teknik Pengumpulan Data}

Metode pengumpulan data yang peneliti gunakan dalam penelitian ini adalah sebagai berikut:

1. Observasi

Yaitu pengumpulan data dengan cara mengadakan pengamatan langsung keadaan yang ada pada suatu organisasi atau instansi yang diteliti yakni tentang analisa alat perlengkapan organisasi dan pegawasan dalam menunjang kinerja karyawan, dalam hal ini Koperasi Green Society Palembang.

2. Wawancara

Wawancara merupakan instrumen pengumpul data yang digunakan penulis untuk memperoleh informasi langsung dari sumbernya tentang analisa alat perlengkapan organisasi dan pegawasan dalam menunjang kinerja karyawan.

F. Teknik Analisis Data

Menurut Mudrajad (2014) metode analisis terdiri dari :

a. Analisis kuantitatif

Analisis kuantitatif adalah suatu metode analisis data yang diukur 
dalam suatu skala numerik (angka).

b. Analisis Kualitatif

Analisis kualitatif adalah suatu metode analisis data yang diukur dengan cara memberikan penjelasan dalam bentuk katakata atau dalam bentuk kalimat.

Analisis data yang akan digunakan dalam penelitian yang akan dilakukan adalah analisis kualitatif, yaitu dengan menjelaskan atau menguraikan dengan menggunakan teori-teori yang berkaitan dengan objek penelitian.

\section{G. Hasil dan Pembahasan}

Pada bagaian ini penulis akan menganalisa peranan alat perlengkapan organisasi dan pengawasan dalam menunjang kinerja karyawan pada Koperasi Green Society Palembang. Adapun peranan alat perlengkapan organisasi dan pengawasan pada Koperasi Green Society Palembang adalah sebagai berikut :

\section{1) Rapat Anggota Tahunan}

Rapat Anggota Tahunan yaitu rapat anggota yang diadakan dalam rangka tutup tahun buku, yang diselenggarakan setahun sekali paling lambat tiga bulan setelah tutup tahun buku. Acara Rapat Anggota Tahunan memuat antara lain :
a. Pembukaan
b. Pembacaan dan pengesahan berita acara Rapat Angota yang lampau.
c. Laporan pertanggungjawaban pengurus tentang kegiatannya selama tahun kerja yang lalu dengan menyediakan neraca dan perhitungan keuangan tahunan serta surat bukti yang perlu.
d. Laporan pengawas
e. Pengesahan laporan pengurus

f. Pengesahan rencana kerja untuk tahun buku berikutnya dan peninjauan anggaran belanja untuk tahun buku yang berjalan.

g. Pengesahan tentang pembagian dan penggunaan. Sisa Hasil Usaha (SHU).

h. Pemilihan anggota pengurus dan anggota pengawas

i. Tanya jawab/usul.

j. Penutup.

Neraca dan perhitungan keuangan tahunan dikirim oleh pengurus kepada pejabat dalam tempo satu (1) bulan sesudah disahkan oleh Rapat Anggota. Rapat Anggota Tahunan Koperasi Green Society Palembang mempunyai wewenang dan kekuasaan yaitu:

a. Mempertimbangkan, menolak ataupun mengesahkan laporan pertanggung jawaban pengurus dan pegawas mengenai kegiatan organisasi usaha dan keuangan koperasi selama tahun buku yang lalu.

b. Mempertimbangkan, menolak ataupun mengesahkan rencana kerja dan rencana anggaran pendapatan dan belanja tahunan koperasi untuk satu tahun yang akan datang.

c. Memilih atau mengganti anggota pengurus dan pengawas serta mencatat atau memberhentikan bila mana terbukti melakukan perbuatan atau tindakan sebagai berikut:

1) Telah melakukan tindakan yang bertentangan dengan keputusan dan kepentingan Rapat Anggota

2) Tidak mentaati ketentuanketentuan dalam Anggaran Dasar dan peraturan-peraturan pelaksanaannya.

3) Dalam tingkah perbuatannya menimbulkan pertentangan dalam gerakan Koperasi. 
d. Mengatur tentang pembagian dan penggunaan Sisa Hasil Usaha (SHU)

e. Mengatur atau memutuskan hal-hal yang menyangkut kehidupan koperasi.

Adapun tata tertib Rapat Anggota Tahunan Koperasi Green Society Palembang adalah sebagai berikut:

\section{> Status Rapat, Waktu dan Tempat}

a) Status Rapat

1. Rapat ini adalah Rapat Anggota Tahunan (RAT)

2. Rapat Anggota Tahunan adalah kekuasaan tertinggi di koperasi (Anggaran Dasar Pasal 27 ayat 1)

3. Sesuai dengan Anggaran Rumah Tangga Bab IV Pasal 14 ayat 1 dari Koperasi Green Society Palembang yang berbunyi: Rapat Anggota Tahunan adalah rapat yang dihadiri oleh wakil-wakil anggota/wakil anggota yang ditunjuk dari masing-masing saksi.

b) Waktu dan Tempat

Rapat Anggota Tahunan (RAT) diadakan di Kantor Pusat Koperasi Green Society Palembang jalan Soekarno-Hatta No. B64 Palembang.

\section{$>$ Landasan Hukum}

1) Landasan hukum Rapat Anggota Tahunan telah diatur oleh UU No. 17 tahun 2012 dan Anggaran Dasar sehubungan dengan kewajiban setiap koperasi untuk mengadakan Rapat Anggota Tahunan dan kewajiban badan Pengurus dan pengawas untuk memberikan pertanggung jawaban atas segala kegiatan koperasi kepada anggota melalui Rapat Anggota Tahunan.

2) Sesuai dengan Anggaran Dasar pasal 1 yang berbunyi: "Rapat Anggota Tahunan diadakan dalam waktu paling lambat tiga (3) bulan sesudah tutup tahun buku".

$>$ Tujuan Rapat Anggota Tahunan

1) Memenuhi kewajiban yang telah diatur dalam Anggaran Dasar/Anggaran Rumah Tangga Koperasi Green Society Palembang.

2) Mempertanggungjawabkan kepada anggota atas segala kegiatan Pengurus dan Pengawas dalam mengelola koperasi selama tahun kerja.

3) Meminta persetujuan dari anggota atas Rencana Kerja, Rencana Anggaran, Rencana Pendapatan untuk periode kerja berikutnya.

\section{$>$ Syarat Pengambilan Keputusan}

1) Setiap wakil anggota yang hadir mempunyai hak suara.

2) Peninjauan dan pengunjung hanya mempunyai hak berbicara, bila diminta oleh pimpinan sidang dan tidak mempunyai hak suara.

3) Keputusan Rapat Anggota ini sejauh mungkin diambil berdasarkan hikmah kebijaksanaan dalam permusyawaratan. Jika tidak tercapai mufakat maka keputusan diambil berdasarkan suara terbanyak dari wakil anggota yang hadir.

> Pimpinan Sidang selama Rapat Anggota Tahunan Berlangsung

Pimpinan sidang Rapat Anggota Tahunan adalah Ketua Badan Pengurus atau yang ditunjuk oleh peserta Rapat Anggota Tahunan dan dibantu oleh wakil Ketua Badan Pengurus atau yang ditentukan oleh sidang.

\footnotetext{
$>$ Pencatatan dalam Rapat Anggota Tahunan (Notulen)

Dilakukan oleh Sekretaris I dan II Badan Pengurus serta Sektertaris Pengawas.
} 
Berdasarkan hasil analisa yang telah penulis lakukan dapat diketahui bahwa Koperasi Green Society Palembang mengadakan Rapat Tahunan selambat-lambatnya pada awal Februari setiap tahunnya. Dalam Rapat Anggota Tahunan salah satu tugas pengurus adalah mengajukan Rencana Kerja untuk tahun berikutnya, yang didasarkan atas usul-usul ataupun keputusan Rapat Anggota Tahunan itu sendiri. Ini berarti Pengurus sejak awal tahun sudah mempunyai rencana kerja setiap tahunnya. Rencana kerja ini dilengkapi dengan Rencana Anggaran Pendapatan dan Belanja Koperasi. Kedua rencana ini digunakan oleh Rapat Anggota sebagai pemegang kekuasaan tertinggi untuk melaksanakan keseluruhan aktivitas koperasi. Hal ini menunjukkan bahwa rapat anggota telah melaksanakan tugas dan fungsinya sebagaimana yang diatur dalam Undang-Undang Nomor 17 Tahun 2012.

\section{2) Pengurus Harian}

Sebagaimana biasa bahwa pada suatu organisasi koperasi di perlukan pengurus yang bertugas untuk mengelola dan menjaga kelangsungan hidup dari suatu koperasi. Pemilihan pengurus Koperasi Green Society Palembang dilaksanakan dalam rapat anggota. Keberhasilan pengurus koperasi sangat tergantung pada faktor manajemennya, sedangkan manajemen koperasi itu terletak pada tri tunggal yang memegang tampuk kepemimpinan dalam koperasi yang merupakan manajemen team. Pengurus koperasi sebagai pemegang mandat dari anggota harus melakukan pekerjaannya secara terbuka sesuai dengan keputusan-keputusan dalam rapat anggota. Kegiatan yang dijalankan berdasarkan rencana kerja yang sudah ditetapkan dalam rapat anggota. Pengurus secara periodik perlu mengadakan rapat pengurus, untuk mengambil keputusan guna melaksanakan rencana koperasi yang ditetapkan dalam rapat anggota tahunan. Dalam hal ini pengurus Koperasi Green Society Palembang dipilih dari dan oleh anggota dalam suatu rapat anggota. Masa jabatan pengurus ditentukan dalam Anggaran Dasar dengan ketentuan tidak boleh lebih dari 5 (lima) tahun.

Adapun pengurus Koperasi Green Society Palembang sebulan sekali membahas laporan bulanan koperasi. Kemudian Rapat Lengkap Pengurus bersama Pengawas setiap 3 (tiga) bulan sekali membahas aktivitas Koperasi selama periode berjalan dan penyempurnaan rencana kerja berikutnya bila ada.

Periode Kepengurusan pada Koperasi Green Society Palembang biasanya setiap 3 (tiga) tahun, setelah itu dapat dipilih kembali atau diganti. Pergantian terjadi karena adanya mutasi atau pindah ke kota lain sehingga dengan sendirinya diadakan pergantian.

Adapun syarat-syarat yang perlu dipertimbangkan untuk dapat menjadi Pengurus Koperasi Green Society Palembang adalah:

a. Mempunyai sifat kejujuran dan keterampilan bekerja

b. Percaya kepada koperasinya, mengadakan inventerisasi dan aktif dalam usaha koperasi

c. Mampu dan cakap untuk mengambil keputusan bagi kepentingan organisasi

d. Dapat bekerjasama dengan yang lain-lain sebagai sebuah team, dan menyokong keputusankeputusan yang diambil dengan suara terbanyak.

e. Jangan memberikan keistimewaan yang khusus bagi 
dirinya sendiri, saudara-saudara atau kawan-kawan.

f. Jangan memperbincangkan dengan pihak luar persoalan yang dirahasiakan dalam rapat-rapat pengurus.

g. Mempunyai pikiran yang maju untuk dapat mengembangkan ide baru yang dapat membantu berhasilnya usaha organisasi koperasi.

Berdasarkan hasil analisa yang penulis lakukan, dapat diketahui bahwa pengurus harian yang ada pada Koperasi Green Society Palembang telah melakukan tugas dan kewajibannya sebagaimana mestinya, akan tetapi jika ada seorang pengurus harian yang berhenti karena suatu alasan tertentu, maka pergantian pengurus harian tersebut jarang dilakukan. Hal ini terjadi karena pengurus harian yang berhenti tersebut dapat digantikan fungsi dan tugasnya oleh pimpinan koperasi itu sendiri, kecuali jika pengurus yang berhenti atau mengundurkan diri tersebut lebih dari 2 orang, maka pergantian akan langsung dilakukan ketika diadakan rapat pembahasan laporan bulanan koperasi.

\section{3) Pengawas}

Menurut Wursanto (2003), "Pengawasan adalah kegiatan membandingkan antara hasil nyata yang dicapai dengan standar yang telah ditetapkan." Selain itu, menurut Terry (2009), "Pengawasan atau controlling mencakup kelanjutan tugas untuk melihat apakah kegiatankegiatan yang dilaksanakan sesuai dengan rencana". Dalam koperasi, pegawasan sebagian dari fungsi manajemen. Tujuannya bukan mencari kesalahan sehingga hubungan pimpinan, karyawan dan anggota menjadi renggang, tetapi mengaja agar pelaksanaan pekerjaan sesuai dengan rencana atau program yang telah disusun. Pengawasan bertujuan untuk mendidik, membimbing supaya menjadi lebih terarah sehingga koperasi menjadi lebih berkembang

Adapun peranan pengawas sebagai berikut :

1) Sebagai alat Perlengkapan Organisasi Koperasi, telah dipercayakan untuk :

a. Menjaga kebenaran hakekat koperasi agar lestari

Dalam hal ini pengawas harus menjaga dan mengamati secara teratur agar peraturan intern koperasi seperti Anggaran Dasar dan Anggaran Rumah Tangga serta keputusan rapat anggota yang berlaku senantiasa dipenuhi oleh pengurus, anggota, manajer, dan karyawan lainnya.

b. Mengamankan kepentingankepentingan Koperasi anggota dan pihak-pihak lainnya serta mengawasi atas pelaksanaan kegiatan usaha agar hasil yang dicapai sesuai dengan rencana yang dituangkan dalam program.

\section{2) Pengawas Sebagai Team Managemen}

a. Mendorong untuk tercapainya pelaksanaan usaha yang efktif dan efesien. Yang terjadi dalam koperasi baik menyangkut organisasi, manajemen administrasi, usaha dan keuangan dengan jalan memberikan saran atau usul.

b. Memberikan informasi yang obyektif tentang kondisi perkembangan dan hasil yang dicapai koperasi kepada anggota dan pejabat.

c. Mendampingi pengurus bila diadakan pemeriksaan oleh pihak luar. 
3) Pengawas Sebagai Pelindung

a. Melindungi kepentingan koperasi atau anggota

b. Menjaga agar kekayaan koperasi penggunaannya secara sehat dan kegiatan usaha sesuai dengan kepentingan dan kebutuhan anggota.

c. Ikut menilai jalannya usaha

Pengawas harus bertanggung jawab kepada Rapat Anggota. Tanggung jawab berarti keharusan menyelesaikan tugas yang dibebankan, maka yang harus dipertanggung jawabkan oleh pengawas terhadap Rapat Anggota adalah hasil pelaksanaan tugas-tugas.

Berdasarkan hasil analisa yang penulis lakukan, dapat diketahui bahwa pengawas yang ada di Koperasi Green Society Palembang telah melaksanakan tugas dan fungsi sebagaimana mestinya, hal ini dapat diketahui berdasarkan laporan-laporan yang diberikan oleh pengawas kepada Rapat Anggota yang menunjukkan bahwa tugas dan fungsinya telah dilaksanakan dengan baik. Adapun kendala yang dihadapi pengawas adalah terlalu luasnya wilayah kerja Koperasi Green Cooperative Society Palembang yang meliputi 4 kabupaten yakni Kabupaten Ogan Komering Ulu (OKU), Kabupaten Ogan Komering Ulu Timur (OKUT), Kabupaten Ogan Komering llir (OKI), dan Kabupaten Ogan llir (OI) sehingga terkadang laporan yang diberikan pengawas kurang lengkap atau bersifat melengkapi saja.

\section{4) Manajer Koperasi}

Manajer adalah pelaksana tugas Pengurus sehari-hari di bidang usaha. Manajer bertanggung jawab kepada Pengurus dan bukan kepada Rapat Anggota. Pengurus bertanggung jawab kepada Anggota dalam Rapat Anggota, dengan demikian maka kedudukan Manajer memperoleh wewenang dari Pengurus dan oleh karena itu Manajer bertanggung jawab kepada pengurus.

Manajer koperasi adalah pelaksana tugas pengurus untuk memimpin Perusahaan Koperasi agar dapat berjalan secara efisien dan efektif. Berhasil tidaknya suatu pengelolaan koperasi tergantung juga kepada Manajer. Manajer ialah orang yang menggerakkan kerja sama orangorang dan alat-alat untuk mencapai tujuan. Daya kepemimpinan seorang manajer terletak pada kesanggupan membantu orang-orang yang dapat bekerja sama secara tepat guna.

Adapun fungsi dari pada Manajer adalah :

1) Melaksanakan kegiatan usaha yang dipercayakan dan dikuasakan kepadanya oleh pengurus.

2) Mempunyai dan mengkoordinasi pekerjaan para karyawan yang berada dibawah pimpinannya.

3) Mempertanggung jawabkan seluruh tugasnya kepada pengurus

Pada umumnya seorang manajer akan dapat bekerja secara efektif kalau ia memenuhi persyaratan-persyaratan sebagai berikut :

1) Mempunyai sikap mental yang baik (jujur, dan lain-lain)

2) Sehat rohani dan jasmani

3) Mempunyai pengetahuan dalam bidang perkoperasian usaha dan berpengalaman dalam bidang perkoperasian

4) Memiliki jiwa kewiraswastaan

5) Bisa bekerja sama dengan pihak lain dan memiliki jiwa kepemimpinan

6) Berinisiatif dan kreatif

7) Mempunyai pengetahuan tentang pembukuan 
8) Mau menandatangani kontrak kerja dan bersedia bekerja secara full time.

9) Harus selalu mampu mendorong dirinya untuk memanfaatkan segala sektor yang dikuasainya, termasuk juga keterampilan usahanya serta waktunya, secara seefisien mungkin diukur atas dasar tujuan usaha koperasinya.

10) Taqwa Kepada Tuhan Yang Maha Esa

Sedangkan peranan Manajer adalah sebagai berikut :

1) Kedudukan dan fungsi pelaksanaan dibidang usaha dan bertanggung jawab kepada Pengurus koperasi

2) Sebagai pelaksanaan dari kebijaksanaan pengurus

3) Dapat menetapkan struktur organisasi dan menajemen koperasi serta menjamin kelangsungan usaha

4) Dapat bekerja terus selama tidak bertentangan dengan Anggaran Dasar dan keputusan rapat anggota, sekalipun ada penggantian pengurus.

5) Mengembangkan sikap percaya atas kekuatan dan kemampuan koperasi sendiri dalam kegiatankegiatan.

Hubungan kerja sama antara pengurus, pengawas, dan pelaksanaan Usaha Manajer. Untuk mengadakan pemisahan yang tegas antara tugas masing-masing maka dibuat pedoman/ketentuan sebagai berikut :

1) Pengurus adalah pelaksanaan dari pada tanggung jawab terhadap Rapat Anggota

2) Pengawas adalah anggota koperasi yang ditunjuk dan dipilih dalam Rapat Anggota untuk mengawasi dari pada kebijaksanaan Pengurus dan dapat memberikan saran-saran demi kemajuan ekonomi.

3) Pelaksanaan kerja (Manajer), yang bukan anggota pengurus melainkan sebagai petugas pelaksana pekerjaan sehari-hari yang bertanggung jawab terhadap pengurus.

Pada Koperasi Green Society Palembang, Manajer di sini melaksanakan jalannya organisasinya dibantu oleh dua orang staf yaitu di bidang keuangan dan di bidang umum. Untuk pelaksanaan pengawasan Manajer berdasarkan atas rencana dari unit-unit, kemudian laporan aktivitas unit-unitnya. Manajer telah menyusun rincian pekerjaan (job description) dari masing-masing karyawan Koperasi Green Society Palembang, dan menyusun mekanisme kerja termasuk sistem dan prosedur, serta penyempurnaan rangking dan imbalan jasa Koperasi Green Society Palembang.

Untuk memperluas dan membahas kebijaksanaan dalam kegiatan usaha dan mengevaluasi usaha-usaha yang ada dalam rangka peningkatan efisiensi serta dalam rangka menyusun rencana pengembangan usaha yang ada dan melaksanakan rencana tersebut, maka sasaran dari pada penyusunan rincian kerja organisasi Koperasi Green Society Palembang ini adalah bertujuan untuk menyempurnakan sistem akuntansi serta sistem pelaporan yang membahas segala hasil penyempurnaan bersama Pengawas dan membahas jadwal rapat rutin pengurus dan pengawas dalam rangka meningkatkan koordinasi kerja.

Dari hasil pengendalian yang dilakukan oleh Pengawas, Pengurus dan Manajer maka dilakukan evaluasi kemudian Pengurus melaporkan hasilnya kepada : 
1) Rapat Anggota Tahunan

2) Laporan Tertulis Bulanan yang ditujukan kepada Kantor Dinas Koperasi dan Usaha Kecil Menegah Pemerintah Kota Palembang.

3) Pengawas

Berdasarkan hasil analisa yang penulis lakukan, dapat diketahui bahwa agar tercipta kesinambungan antara Pengawas dan pengevaluasian yang dilakukan oleh pengurus dan Manajer, maka proses pelaksanaan penganalisaan dilakukan secara bersama-sama dengan tujuan akan dapat menganalisa keadaan terhadap permintaan anggota dalam memenuhi kebutuhannya. Hal ini menunjukkan bahwa salah satu alat perlengkapan koperasi yang terdapat pada Koperasi Green Society Palembang yakni Manajer Koperasi telah melaksanakan peranannya sebagaimana mestinya.

\section{5) Sistem Administrasi Koperasi}

Koperasi sebagai organisasi ekonomi yang melakukan kegiatan usaha atau perusahaan harus melakukan prinsip-prinsip ekonomi atau perusahaan juga antara lain tercermin dalam tata laksana dan tata pembukuan atau administrasi usaha dan keuangannya. Jadi koperasi juga mengenal tutup tahun buku yang diselenggarakan setiap tahunnya. Pembukuan harus dilakukan dengan teratur menurut sistem atau pola yang cocok dengan kondisi koperasi, di mana koperasi yang mempunyai usaha yang banyak tentunya pembukuannya memerlukan cara atau sistem yang lain dari pada koperasi yang hanya mempunyai unit usaha yang sederhana saja.

Ketertiban

pembukuan administrasi usaha umumnya menjadi ukuran berhasil tidaknya pengelolaan usaha koperasi tersebut dan merupakan alat pengawasan atau pegensalian yang efektif dari pada kebenaran pelaksanaan usaha koperasi.

Berdasarkan hasil analisa yang penulis lakukan, dapat diketahui bahwa sistem administrasi yang digunakan oleh Koperasi Green Society Palembang adalah Sistem Administrasi Keuangan yang meliputi antara lain :

1) Sistem dan prosedur

2) Sistem Akuntansi

3) Sistem Pelaporan

Bila ditinjau dari segi manajemennya koperasi ini telah menerapkan Sistem Managemen Terbuka dengan cara setiap awal bulan masing-masing anggota mendapat surat pemberitahuan mengenai antara lain: posisi keuangan dan usaha, jumlah simpan pinjam masing-masing anggota serta keadaan koperasi secara keseluruhan.

Keadaan ini merupakan faktor yang mampu memotivasi anggota untuk berpartisipasi secara aktif pada kegiatan koperasi. Selain itu dalam upaya mencapai tujuan secara efektif dan efisien koperasi ini telah mengaktifkan fungsi-fungsi panitia yang membantu pengurus memberikan saran dan pendapat dan pendapat pada pengurus mengenai kegiatan yang dilaksanakan. Sedangkan analisa keuangan yang dipergunakan Koperasi Green Society Palembang yaitu Metode Analisa Prosentase. Analisa tersebut sangat erat kaitannya dengan ratio-ratio kemampuan koperasi dalam hal memperoleh laba atas hasil usahanya, sehingga akan dapat dibandingkan dari waktu ke waktu, ataupun untuk usaha badan sejenis. Pada analisa ini selain dari pada usaha-usaha yang sejenis yang dapat dibandingkan, maka akan terlihat pula hasil pengembangan dari usaha badan koperasi. 
Telah penulis uraikan dimuka bahwa pengawasan yang telah dilakukan oleh anggota dan Pengawas telah dilaksanakan sesuai dengan ketentuan yang telah ditetapkan. Dalam hal ini Badan Pengurus menyadari sepenuhnya bahwa masih banyak kelemahan dan kekurangan dalam mengelola koperasi. Temuantemuan yang didapat oleh Pengawas akan selalu mengingatkan akan kelemahan tersebut, dan dapat dijadikan sebagai bahan pada Rapat Anggota yang akan diadakan nanti. Kemampuan Pengurus dan Pengawas dalam mengelola koperasi ini adalah terbatas dan apa yang telah dicapai merupakan usaha maksimal untuk tahun kerja yang lampau, dan akan berusaha bekerja lebih baik lagi agar di tahun-tahun mendatang tetap dapat makin maju lagi, makin mantap, makin kuat, dan makin mandiri.

\section{6) Pengawasan}

Pengawasan adalah proses yang dilakukan oleh seseorang atau sekelompok orang yang bertindak sebagai pengawas demi kelancaran pelaksanaan program-program Koperasi Green Society Palembang.

Peranan Pengawasan adalah bertujuan untuk:

a. Memberikan bimbingan kepada pengurus, karyawan kearah keahlian dan ketrampilan.

b. Mencegah pemborosan bahan, waktu dan tenaga keraha keahlian dan keterampilan.

c. Menilai hasil kerja sama dengan rencana yang sudah ditetapkan.

d. Mencegah terjadinya penyelewengan.

e. Pelaksanaan administrasi yang baik secara menyeluruh.

Bentuk Pengawasan terdiri dari:

1) Pengawasan yang diangkat pengurus.
2) Pengawasan yang diangkat manajer.

3) Pengawasan yang diangkat Rapat Anggota.

4) Pengawasan yang diangkat Jawatan koperasi.

Pengawas yang diangkat Rapat Anggota telah diatur dalam UndangUndang Perkoperasian dan Anggaran Rumah Tangga. Adapun hal-hal yang perlu diperiksa antara lain:
a. Uraian tentang keadaan keuangan
b. Kegiatan usaha, biaya operasional, pendapatan dan sebagainya.

c. Analisa tentang kekayaan koperasi dengan memperlihatkan cara-cara penggunaannya.

d. Analisa mengenai kekayaankekayaan dan kewajibankewajiban yang terpenting jatuhnya waktu

e. Masalah-masalah perkreditan dan penggunaannya sesuai dengan kebijaksanaan yang telah ditetapkan

f. Penelitian tentang pelaksanaan operasional, sesuai dengan anggaran rumah tangga dan ketentuan-ketentuan yang lain.

g. Koperasi benar-benar bekerja sesuai dengan kebijaksanaankebijaksanaan yang telah diputuskan oleh pengurus.

Berdasarkan analisa yang penulis lakukan, dapat diketahui bahwa pengawasan yang dilakukan di Koperasi Green Society Palembang telah dilakukan sebagaimana mestinya walaupun pada kenyataannya pada bagian tertentu seperti pengawasan yang dilakukan pengurus dan pengawasan yang dilakukan oleh bagian pengawas belumlah maksimal, hal ini dikarenakan kemampuan pengurus dan pengawas dalam mengelola koperasi ini serta 
kemampuan individu seperti pengetahuan mengenai pengawasan itu sendiri adalah terbatas, hal ini antara lain diakibatkan karena terlalu luasnya wilayah kerja koperasi ini dan kurangnya Sumber Daya Manusia yang berkualitas, sehingga apa yang telah dicapai merupakan usaha maksimal sesuai dengan kemampuan mereka untuk tahun kerja yang lampau.

\section{H. Kesimpulan dan Saran \\ 1. Kesimpulan}

Berdasarkan hasil penelitian yang telah dilakukan, dapat disimpulkan halhal sebagai berikut:

a. Pengurus koperasi sejak awal tahun sudah mempunyai rencana kerja setiap tahunnya. Hal ini dapat dilihat dari diadakannya Rapat Tahunan selambatlambatnya pada awal Februari setiap tahunnya yang membahas antara lain tentang Rencana Kerja untuk tahun berikutnya. Hal ini menunjukkan bahwa rapat anggota telah melaksanakan tugas dan fungsinya sebagaimana yang diatur dalam UndangUndang Nomor 2 Tahun 1992.

b. Pengurus harian telah melakukan tugas dan kewajibannya sebagaimana mestinya, akan tetapi jika ada seorang pengurs harian yang berhenti karena suatu alasan tertentu, maka pergantian pengurus harian tersebut jarang dilakukan. Hal ini terjadi karena pengurus harian yang berhenti tersebut dapat digantikan fungsi dan tugasnya oleh pimpinan koperasi itu sendiri, kecuali jika pengurus yang berhenti atau mengundurkan diri tersebut lebih dari 2 orang, maka pergantian akan langsung dilakukan ketika diadakan rapat pembahasan laporan bulanan koperasi. c. Pengawas telah melaksanakan tugas dan fungsi sebagaimana mestinya, hal ini dapat diketahui berdasarkan laporan-laporan yang diberikan oleh pengawas kepada Rapat Anggota yang menunjukkan bahwa tugas dan fungsinya telah dilaksanakan dengan baik. Kendala yang dihadapi pengawas adalah terlalu luasnya wilayah kerja Koperasi yang meliputi 4 kabupaten sehingga terkadang laporan yang diberikan pengawas kurang lengkap atau bersifat melengkapi saja.

d. Proses pelaksanaan penganalisaan dilakukan secara bersama-sama antara pengurus dan manajer dengan tujuan akan dapat menganalisa keadaan terhadap permintaan anggota dalam memenuhi kebutuhannya. Hal ini menunjukkan bahwa salah satu alat perlengkapan koperasi yakni Manajer Koperasi telah melaksanakan peranannya sebagaimana mestinya.

e. Manajemen koperasi menerapkan Sistem Managemen Terbuka dengan mengaktifkan fungsifungsi panitia yang membantu pengurus memberikan saran dan pendapat dan pendapat pada pengurus mengenai kegiatan yang dilaksanakan. Aanalisa keuangan yang dipergunakan adalah Metode Analisa Prosentase. Pada analisa ini selain dari pada usaha-usaha yang sejenis yang dapat dibandingkan, maka akan terlihat pula hasil pengembangan dari usaha badan koperasi.

f. Pengawasan telah dilakukan sebagaimana mestinya, walaupun pada kenyataannya pada bagian tertentu seperti pengawasan yang dilakukan pengurus dan 
pengawasan yang dilakukan oleh bagian pengawas belumlah maksimal, hal ini terjadi karena terlalu luasnya wilayah kerja koperasi ini. Selain itu kemampuan individu seperti pengetahuan mengenai pengawasan itu sendiri adalah terbatas, dan kurangnya Sumber Daya Manusia yang berkualitas, sehingga apa yang telah dicapai merupakan usaha maksimal sesuai dengan kemampuan mereka untuk tahun kerja yang lampau.

\section{Saran}

Adapun saran-saran yang dapat penulis kemukakan adalah sebagai berikut:

a. Dalam usaha untuk mencapai tujuan organisasi, maka perlu bagi Koperasi Green Society Palembang menjalankan prinsipprinsip organisasi, prinsip-prinsip pembagian kerja, prinsip wewenang dan tanggung jawab, prinsip koordinasi, dan prinsip jangkauan pengawasan.

b. Anggota sebagai pemilik koperasi, agar terus meningkatkan pertisipasi aktif dalam setiap kegiatan usaha maupun kegiatan organisasi untuk perkembangan dan kemajuan koperasi di masa yang akan datang.

c. Perlunya pengawasan atau pengendalian yang bersifat menyeluruh oleh pengawas untuk semua aktivitas yang dijalankan

d. Diharapkan kepada Pengurus segera mengambil langkahlangkah untuk mengadakan perbaikan sesuai dengan saran Pengawas. e. Dalam proses pengambilan keputusan, sebaiknya para pengurus koperasi sebagai pembantu ketua koperasi sejalan dengan keputusan yang diambil oleh Ketua Koperasi.

f. Ketua koperasi sebagai pengawas koperasi seharusnya senantiasa berada atau hadir di koperasi sehingga dapat mengoptimalkan pengawasan. Selama ini ketua koperasi jarang hadir di koperasi dan sering berada di luar koperasi.

\section{DAFTAR PUSTAKA}

Arikunto, Suharsimi. 2010. Prosedur Penelitian : Suatu pendekatan praktik, yogyakarta : Rineka Cipta

Dirjen Pendidikan Tinggi. UUD 1945, $P-4, G B H N$. Jakarta: Departemen Pendidikan dan Kebudayaan.

Hendrojogi. 2012. Koperasi, Azas-Azas Teori dan Praktek. Jakarta: Raja Grafindo Persada.

Kuncoro, Mudrajat. 2014. Metode Riset Untuk Bisnis dan Ekonomi. Jakarta: Erlangga.

Terry, Goerge R. 2009. Prinsip-Prinsip Manajemen. Jakarta : Bumi Aksara.

Tim Penyusun. Undang-Undang Dasar 1945 dan Amandemennya. Jakarta: Fokus Media.

UU Koperasi No.17/2012. Tentang Pokok-pokok Perkoperasian.

Wursanto, Ig. 2003. Dasar-Dasar IImu Organisasi. Yogyakarta: Andi. 